\title{
UPPER MANTLE VELOCITY STRUCTURE IN THE NEW HEBRIDES ISLAND ARC REGION
}

\author{
K.L. KAILA and V.G. KRISHNA \\ National Geophysical Research Institute, Hyderabad, India
}

(Received April 25, 1978; Revised August 8, 1978)

\begin{abstract}
Upper mantle velocity structure in the New Hebrides island arc region has been determined to a depth of $240 \mathrm{~km}$ from the analysis of $\mathrm{P}$ and $\mathrm{S}$ wave travel times of 39 deep earthquakes using KAILA's (1969) analytical method. The present analysis reveals a linear increase of $P$ wave velocity from $8.06 \mathrm{~km} / \mathrm{sec}$ at a $40-\mathrm{km}$ depth to $8.19 \mathrm{~km} / \mathrm{sec}$ at a $240-\mathrm{km}$ depth with a gradient of only $0.06 \pm 0.01 \mathrm{~km} / \mathrm{sec}$ per $100 \mathrm{~km}$. For S waves also, the velocity increases linearly from $4.55 \mathrm{~km} / \mathrm{sec}$ at a $40-\mathrm{km}$ depth to $4.64 \mathrm{~km} / \mathrm{sec}$ at a depth of $220-\mathrm{km}$ with a gradient of only $0.04 \pm 0.02 \mathrm{~km} / \mathrm{sec}$ per $100 \mathrm{~km}$. The velocity gradients for $\mathrm{P}$ and $\mathrm{S}$ waves, from 40 to $240 \mathrm{~km}$ depth in the upper mantle beneath the New Hebrides arc are found to be extremely small as compared to those at similar depths in the adjacent Tonga-Kermadec-New Zealand region. Consequantly, the $\mathrm{P}$ and $\mathrm{S}$ velocities, to a depth of $240 \mathrm{~km}$, beneath the New Hebrides arc are found to be about $6 \%$ lower, on the average, than those in the Tonga-Kermadec-New Zealand region. This velocity difference is attributed primarily to very high upper mantle temperatures in the New Hebrides region which may be about $1,000^{\circ} \mathrm{C}$ higher than those in the Tonga-Kermadec-New Zealand region. An alternative explanation based on existence of high temperatures in this region is also presented which explains deep seismic activity at $600 \mathrm{~km}$ depth in the New Hebrides region without invoking the concept of a detached lithospheric slab proposed by some of the earlier workers.
\end{abstract}

\section{Introduction}

The New Hebrides island arc region in the southwest Pacific forms a belt of great seismic activity to intermediate depths extending from $10^{\circ} \mathrm{S}, 166^{\circ} \mathrm{E}$ to $24^{\circ} \mathrm{S}, 172^{\circ} \mathrm{E}$ and a belt of active volcanism is also associated with it. The intermediate depth earthquakes in this region occur along the northeasternly dipping New Hebrides seismic zone which appears as a plane dipping at about $30^{\circ}$ at shallow depths and about $70^{\circ}$ at intermediate depths (PASCAL et al., 1973). There is a remarkable gap in seismic activity between depths of about $300-600 \mathrm{~km}$ in this region. Deep focus earthquakes with depths greater than $600 \mathrm{~km}$ are concentrated mainly in a region northeast of the New Hebrides arc although a very few deep earthquakes have also occurred in the southern part of the New Hebrides arc. However, the deep earthquake activity in this region is very limited. Barazangr et al. (1973) studied the seismic wave propagation beneath the New Hebrides island arc and interpreted the gap in seismic activity between deep and intermediate depth earthquakes at the northern part of the arc as corresponding to a gap in the lithospheric slab descending beneath the arc. They interpreted the deep earthquakes occurring in the northeastern region of the arc as representing a detached piece of lithosphere. PASCAL et al. (1973) found that the observed travel time residuals along the New Hebrides arc can be explained by $\mathrm{P}$ travel times computed for a velocity model which includes a $6 \%$ higher velocity relative to a normal mantle inside a dipping lithospheric slab $300 \mathrm{~km}$ deep, a $6 \%$ 
higher velocity inside a detached slab at a depth of $600 \mathrm{~km}$, and a $4 \%$ lower velocity in the wedge of the mantle above the inclined seismic zone. However, these are only the estimates of relative differences of the velocity structure in different parts of the upper mantle and the actual velocity structure as a function of depth, for $\mathrm{P}$ and $\mathrm{S}$ waves, is not well known in the New Hebrides island arc region. In the present study, we have determined the upper mantle velocity structure to a depth of $240 \mathrm{~km}$ in the inclined seismic zone beneath the New Hebrides island arc region from the analysis of $\mathrm{P}$ and $\mathrm{S}$ wave travel times. The resulting velocity functions for $\mathrm{P}$ and $\mathrm{S}$ waves are compared with those determined by KAILA and KRISHNA (1978) for the Tonga-Kermadec-New Zealand region and also with the velocity functions for various regions of the earth determined by other workers. The gross differences in the velocity structure between the New Hebrides island arc and

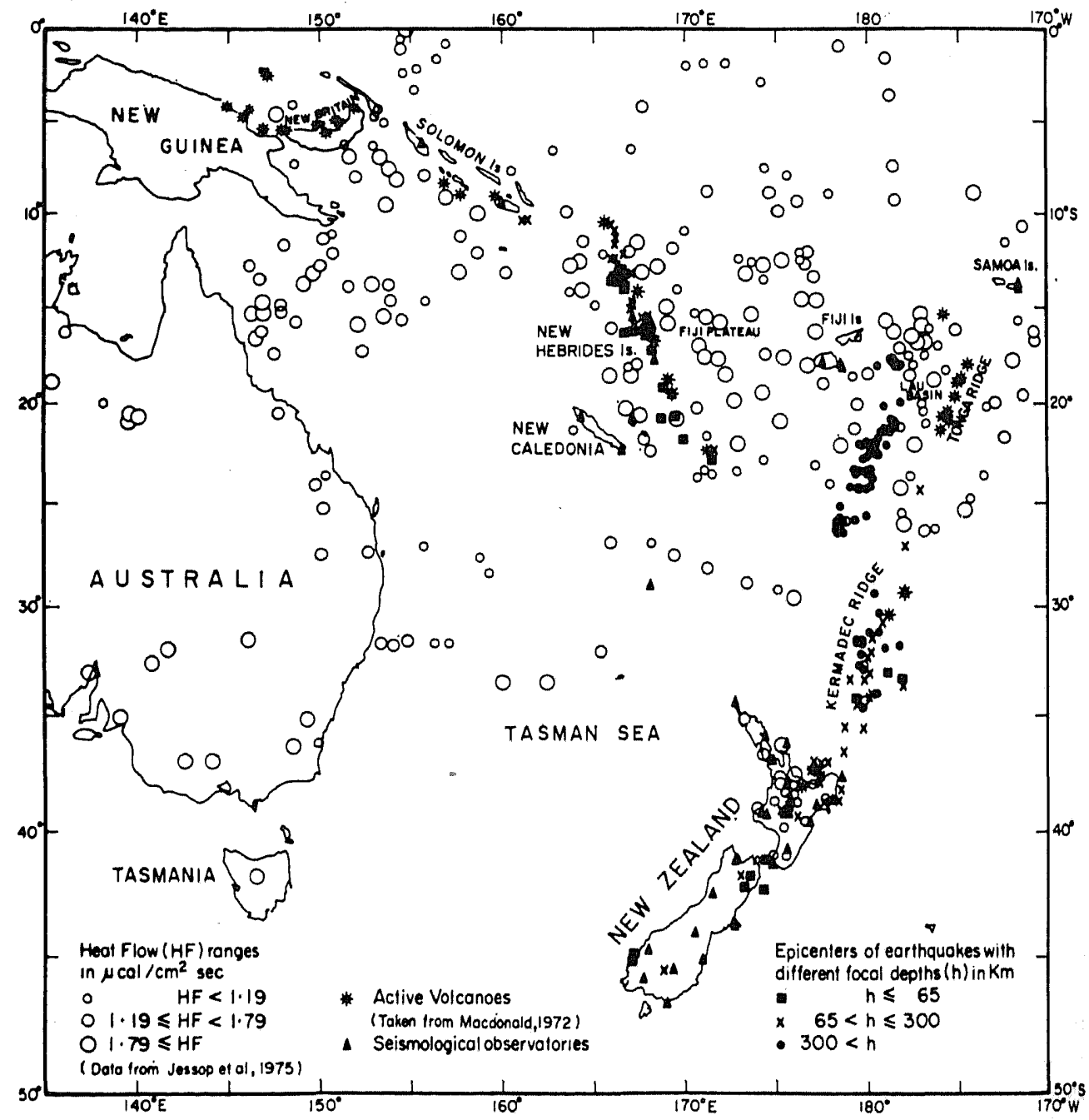

Fig. 1. Map of the southwest Pacific region showing the seismological observatories and epicenters of earthquakes in the New Hebrides region used in the present study. Epicenters of earthquakes used by KAILA and KRIsHNA (1978) for determining the upper mantle velocity structure in the Tonga-Kermadec-New Zealand region are also shown. 
Table 1. Earthquake epicentral data.

\begin{tabular}{|c|c|c|c|c|c|c|c|}
\hline \multirow{2}{*}{$\begin{array}{l}\text { Earth- } \\
\text { quake } \\
\text { No. }\end{array}$} & \multirow[b]{2}{*}{ Date } & \multicolumn{3}{|c|}{ Time } & \multicolumn{2}{|c|}{ Epicenter } & \multirow{2}{*}{$\begin{array}{l}\text { Focal } \\
\text { depth } \\
(\mathrm{km})\end{array}$} \\
\hline & & (h) & $(\mathrm{m})$ & (s) & $\begin{array}{c}\text { Latitude } \\
\text { (deg) }\end{array}$ & $\begin{array}{c}\text { Longitude } \\
\text { (deg) }\end{array}$ & \\
\hline 1 & Mar. 4, 1964 & 03 & 17 & 23.6 & $20.67 \mathrm{~S}$ & $168.59 \mathrm{E}$ & 36 \\
\hline 2 & Nov. 20, 1961 & 11 & 44 & 21.0 & $21.81 \mathrm{~S}$ & $169.88 \mathrm{E}$ & 36 \\
\hline 3 & Oct. 21,1964 & 10 & 08 & 46.7 & $14.10 \mathrm{~S}$ & $166.70 \mathrm{E}$ & 37 \\
\hline 4 & Feb. 7, 1964 & 23 & 12 & 52.8 & $19.24 \mathrm{~S}$ & $168.70 \mathrm{E}$ & 38 \\
\hline 5 & Sept. 16, 1963 & 20 & 05 & 23.0 & $13.39 \mathrm{~S}$ & $166.53 \mathrm{E}$ & 40 \\
\hline 6 & Nov. 3, 1964 & 17 & 07 & 41.8 & $22.80 \mathrm{~S}$ & $171.50 \mathrm{E}$ & 41 \\
\hline 7 & June 6,1964 & 02 & 14 & 11.0 & $16.20 \mathrm{~S}$ & $167.10 \mathrm{E}$ & 41 \\
\hline 8 & Jan. 27, 1964 & 05 & 06 & 59.7 & $13.04 \mathrm{~S}$ & $166.60 \mathrm{E}$ & 41 \\
\hline 9 & Sept. 6, 1960 & 14 & 03 & 01.0 & $20.57 \mathrm{~S}$ & $169.35 \mathrm{E}$ & 44 \\
\hline 10 & Aug. 10, 1964 & 14 & 44 & 40.8 & $14.00 \mathrm{~S}$ & $166.70 \mathrm{E}$ & 44 \\
\hline 11 & Feb. 18, 1964 & 01 & 31 & 18.7 & $16.32 \mathrm{~S}$ & $166.74 \mathrm{E}$ & 50 \\
\hline 12 & Jan. 22,1964 & 23 & 59 & 4.5 .3 & $13.64 \mathrm{~S}$ & $165.96 \mathrm{E}$ & 50 \\
\hline 13 & June 10,1964 & 11 & 53 & 31.0 & $17.16 \mathrm{~S}$ & $168.10 \mathrm{E}$ & 52 \\
\hline 14 & Dec. 24, 1963 & 11 & 18 & 15.0 & $13.17 \mathrm{~S}$ & $166.72 \mathrm{E}$ & 53 \\
\hline 15 & Nov. 6, 1961 & 05 & 28 & 26.0 & $13.38 \mathrm{~S}$ & $166.14 \mathrm{E}$ & 63 \\
\hline 16 & Apr. 17, 1964 & 14 & 44 & 21.3 & 16.19S & $167.50 \mathrm{E}$ & 66 \\
\hline 17 & Dec. 28, 1961 & 23 & 55 & 54.0 & $12.38 \mathrm{~S}$ & $166.16 \mathrm{E}$ & 69 \\
\hline 18 & June 22, 1964 & 03 & 03 & 38.1 & $10.34 \mathrm{~S}$ & $161.11 \mathrm{E}$ & 74 \\
\hline 19 & Nov. 11, 1962 & 16 & 09 & 58.0 & $12.88 \mathrm{~S}$ & $166.41 \mathrm{E}$ & 75 \\
\hline 20 & Aug. 22, 1961 & 08 & 59 & 32.0 & $13.49 \mathrm{~S}$ & $166.46 \mathrm{E}$ & 79 \\
\hline 21 & Aug. 9, 1964 & 05 & 30 & 47.5 & $10.27 \mathrm{~S}$ & $161.30 \mathrm{E}$ & 86 \\
\hline 22 & Apr. 28, 1964 & 15 & 11 & 33.2 & $12.44 \mathrm{~S}$ & $166.01 \mathrm{E}$ & 87 \\
\hline 23 & Mar. 27, 1964 & 08 & 01 & 31.0 & $11.55 \mathrm{~S}$ & $166.20 \mathrm{E}$ & 96 \\
\hline 24 & Nov. 21, 1964 & 06 & 19 & 16.0 & $14.85 \mathrm{~S}$ & $167.24 \mathrm{E}$ & 97 \\
\hline 25 & July 2, 1962 & 08 & 32 & 42.0 & $10.58 \mathrm{~S}$ & $165.99 \mathrm{E}$ & 98 \\
\hline 26 & Apr. 3, 1964 & 19 & 08 & 16.5 & $15.03 \mathrm{~S}$ & $167.04 \mathrm{E}$ & 99 \\
\hline 27 & May 2, 1964 & 10 & 55 & 59.4 & $14.84 \mathrm{~S}$ & $167.23 \mathrm{E}$ & 102 \\
\hline 28 & July 15,1964 & 08 & 24 & 53.6 & $11.34 \mathrm{~S}$ & $166.24 \mathrm{E}$ & 103 \\
\hline 29 & May 22, 1962 & 08 & 06 & 38.0 & $12.24 \mathrm{~S}$ & $166.66 \mathrm{E}$ & 121 \\
\hline 30 & Oct. 5,1964 & 13 & 12 & 13.9 & $22.36 \mathrm{~S}$ & $171.65 \mathrm{E}$ & 130 \\
\hline 31 & June 26,1964 & 05 & 20 & 04.2 & $15.68 \mathrm{~S}$ & $167.79 \mathrm{E}$ & 135 \\
\hline 32 & July 11,1964 & 17 & 32 & 16.7 & $15.54 \mathrm{~S}$ & $167.68 \mathrm{E}$ & 140 \\
\hline 33 & Oct. 24,1964 & 22 & 06 & 07.8 & $16.00 \mathrm{~S}$ & $167.20 \mathrm{E}$ & 141 \\
\hline 34 & Oct. 21,1961 & 17 & 34 & 34.0 & $10.91 \mathrm{~S}$ & $166.19 \mathrm{E}$ & 164 \\
\hline 35 & May 27,1964 & 00 & 54 & 50.8 & $15.52 \mathrm{~S}$ & $167.99 \mathrm{E}$ & 166 \\
\hline 36 & July 16, 1962 & 09 & 25 & 58.0 & $13.16 \mathrm{~S}$ & $167.07 \mathrm{E}$ & 204 \\
\hline 37 & Dec. 5,1961 & 13 & 02 & 37.0 & $16.35 \mathrm{~S}$ & $167.85 \mathrm{E}$ & 205 \\
\hline 38 & Apr. 19, 1962 & 22 & 15 & 24.0 & $15.92 \mathrm{~S}$ & $167.92 \mathrm{E}$ & 223 \\
\hline 39 & Sept. 1, 1962 & 04 & 52 & 14.0 & $15.81 \mathrm{~S}$ & $168.11 \mathrm{E}$ & 238 \\
\hline
\end{tabular}

the Tonga-Kermadec-New Zealand region are interpreted in terms of large lateral temperature variations prevailing even at great depths in the mantle beneath the two oppositely dipping seismic regions. Probable physical and thermal properties of the upper mantle in the New Hebrides region are discussed which provide an alternative explanation for the existance of deep seismic activity at $600 \mathrm{~km}$ depth that has been interpreted by some of the workers (BARAzANgi et al., 1973; PASCAL et al., 1973) as an evidence for a detached piece of lithospheric slab.

\section{Data Analysis and Results}

Thirty-nine shallow and intermediate depth earthquakes are selected in the seismic 
region of the New Hebrides for determining the upper mantle velocity structure in the inclined seismic zone beneath this region. $P$ and $S$ wave travel times and epicentral distances (4) are taken from the bulletins of the International Seismological Summary (ISS) for the period 1960-1963 and from the bulletins of the International Seismological Center (ISC) for the year 1964. The epicenters of all the earthquakes in the New Hebrides region used in the present study along with the seismograph stations are shown in Fig. 1. The epicentral data for all the earthquakes is also given in Table 1.

For obtaining the velocities at various depths in the seismic zone beneath New Hebrides island arc, we have analysed the $\mathrm{P}$ and $\mathrm{S}$ wave travel times of all the earthquakes listed in Table 1 by making use of KAILA's (1969) analytical method. The epicentral distance limits $\Delta_{1}$ and $\Delta_{2}$, between which $p(=\partial T / \partial \Delta)$ is considered to remain stationary, are however not determined from the data for various earthquakes used in the present study. Instead, we have made use of the $\Delta_{1}$ and $\Delta_{2}$ curves plotted as functions of focal depth given by KaIlA et al. (1971, Fig. 9 for $\mathrm{P}$ waves and 1974, Fig. 7 for $\mathrm{S}$ waves) for obtaining the $\Delta_{1}$ and $\Delta_{2}$ limits in each case, because in our opinion these estimates of $\Delta_{1}$ and $\Delta_{2}$ for various focal depths are quite accurate within the error limits and that they do not affect significantly the final velocity estimates. The travel time data available between the two limits is fitted by a least squares line in each case which yields the apparent $p(=\partial T /$ $\partial \Delta$ ) and the $a(=T-p \Delta)$ values with their standard deviations. The least squares fits

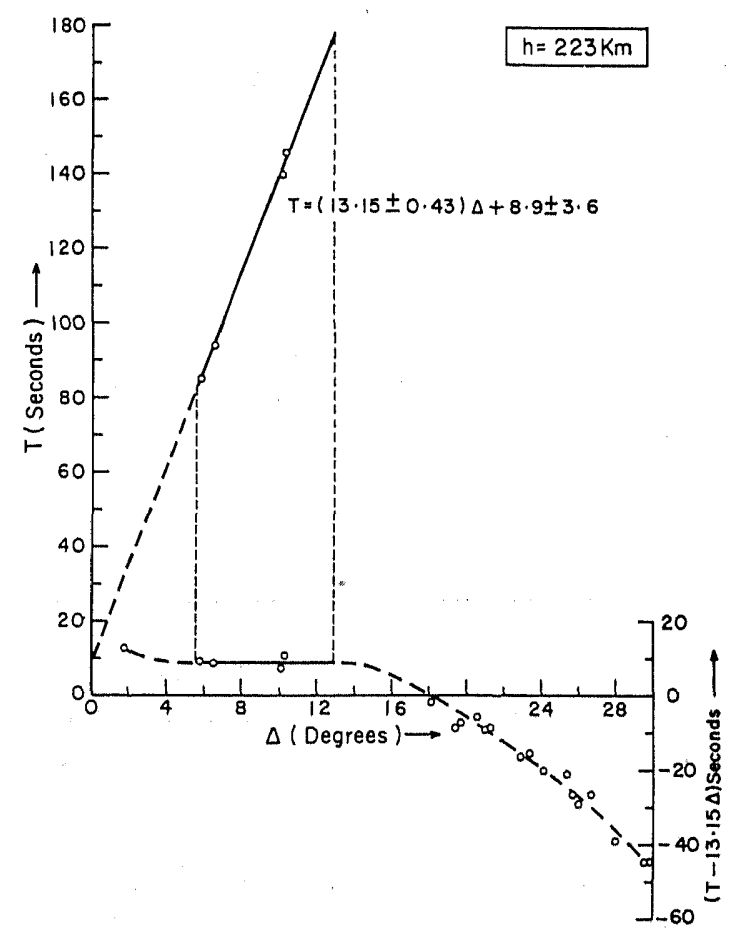

Fig. 2. $\mathrm{P}$ wave travel time curve $T$ versus $\Delta$ for earthquake with focal depth $223 \mathrm{~km}$ between the limits $\Delta_{1}$ and $\Delta_{2}$ of epicentral distance. Reduced travel time curve $(T-p d)$ versus $\Delta$ is also shown where $p=\partial T / \partial \Delta$ at the inflection point. 


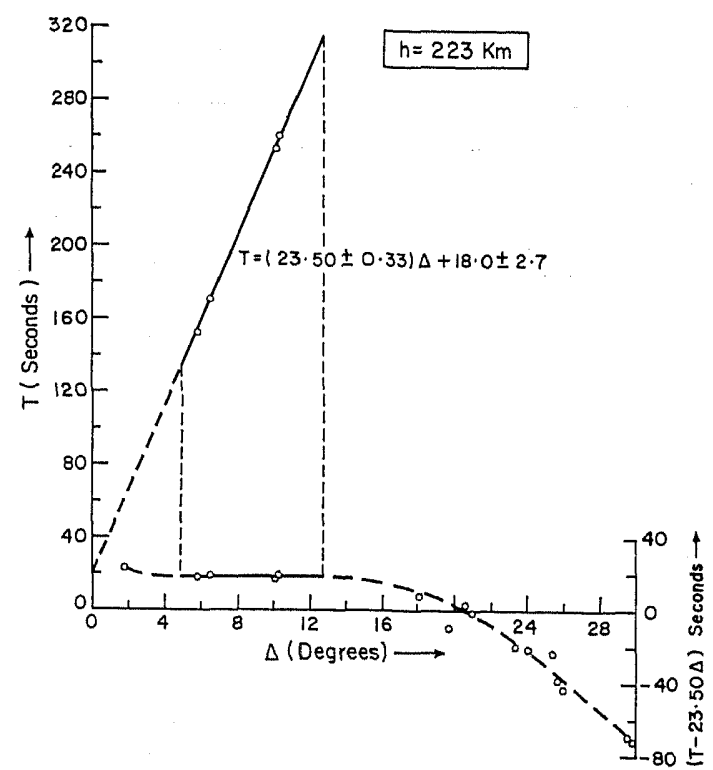

Fig. 3. $\mathrm{S}$ wave travel time curve $T$ versus $\Delta$ for earthquake with focal depth $223 \mathrm{~km}$ between the limits $\Delta_{1}$ and $\Delta_{2}$ of epicentral distance. Reduced travel time curve $(T-p \Delta)$ versus $\Delta$ is also shown where $p=\partial T / \partial \Delta$ at the inflection point.

obtained for $T-\Delta$ points between the $\Delta_{1}$ and $\Delta_{2}$ limits for one specimen earthquake with focal depth $223 \mathrm{~km}$ are shown in Figs. 2 and 3 for $P$ and $S$ waves respectively. In the same figures are also shown the plots $(T-p d)$ versus $\Delta$. Using the apparent $p$ values, the true velocities and their standard deviations are computed for each focal depth analysed. It may be mentioned here that the method of analysis adopted in the present study has the greatest advantage that we are able to determine the velocity for $\mathrm{P}$ and $\mathrm{S}$ waves at the hypocenter of each earthquake thus avoiding completely the effect of the travel path to different stations. Since all the earthquake hypocenters used in the present study are in the inclined seismic zone, the final velocity function resulting on the basis of all these velocity estimates will represent precisely the velocity structure in the inclined seismic zone beneath the New Hebrides island arc. The final results obtained for the $p$ values and velocities with their standard deviations are given in Table 2 for both $\mathrm{P}$ and $\mathrm{S}$ waves.

The true velocities and the $a$ values thus obtained at various depths are plotted as parts (a) and (b) respectively in Fig. 4 for $\mathrm{P}$ waves and in Fig. 5 for $\mathrm{S}$ waves. In these figures the velocity-depth and the $a$ value-depth points are shown by circles and the truncated horizontal bars with them indicate the standard deviations of the plotted points. The velocity-depth points and the $a$ value depth points, for both $\mathrm{P}$ and $\mathrm{S}$ waves, are fitted by straight lines using the method of least squares and are shown by thick lines in Figs. 4 and 5. The broken lines bounding these straight line fits represent the $95 \%$ confidence limits of the slopes in each case.

The velocity functions thus determined in the New Hebrides region reveal very small linear increase of velocity with depth for both $\mathrm{P}$ and $\mathrm{S}$ waves (Figs. $4 \mathrm{a}$ and $5 \mathrm{a}$ respectively). The velocity for $P$ waves determined as $8.06 \mathrm{~km} / \mathrm{sec}$ at a $40 \mathrm{~km}$ depth increases linearly to $8.19 \mathrm{~km} / \mathrm{sec}$ at a depth of $240 \mathrm{~km}$ with a mild velocity gradient of only $0.06 \pm 0.01 \mathrm{~km} / \mathrm{sec}$ 
Table 2. $\quad \mathrm{P}$ and $\mathrm{S}$ wave true velocities $V_{\mathrm{P}}$ and $V_{\mathrm{S}}$ respectively as functions of depth $(h)$ for the New Hebrides region as determined in the present study.

\begin{tabular}{|c|c|c|c|c|c|c|c|}
\hline \multirow{2}{*}{$\begin{array}{l}\text { Earth- } \\
\text { quake } \\
\text { No. }\end{array}$} & \multirow[b]{2}{*}{$\begin{array}{c}h \\
(\mathrm{~km})\end{array}$} & \multicolumn{3}{|c|}{$P$ waves } & \multicolumn{3}{|c|}{$\mathrm{S}$ waves } \\
\hline & & $\begin{array}{c}p(\text { apparent }) \\
(\mathrm{sec} / \mathrm{deg})\end{array}$ & $\begin{array}{c}V_{\mathrm{P}} \\
(\mathrm{km} / \mathrm{sec})\end{array}$ & $\begin{array}{c}a_{\mathrm{P}} \\
(\mathrm{sec})\end{array}$ & $p$ (apparent) & $\begin{array}{c}V_{\mathrm{S}} \\
(\mathrm{km} / \mathrm{sec})\end{array}$ & $\begin{array}{c}a_{\mathrm{S}} \\
(\mathrm{sec})\end{array}$ \\
\hline 1 & 36 & $14.04 \pm 0.51$ & $7.91 \pm 0.29$ & $1.9 \pm 1.8$ & - & - & - \\
\hline 2 & 36 & - & - & - & $25.03 \pm 2.41$ & $4.44 \pm 0.43$ & $11.9 \pm 10.6$ \\
\hline 3 & 37 & $13.45 \pm 0.44$ & $8.25 \pm 0.27$ & $7.7 \pm 3.1$ & - & \pm & - \\
\hline 4 & 38 & $13.73 \pm 0.13$ & $8.09 \pm 0.08$ & $5.1 \pm 0.5$ & - & - & 一 \\
\hline 5 & 40 & $13.88 \pm 0.49$ & $8.00 \pm 0.28$ & $4.8 \pm 3.2$ & - & - & - \\
\hline 6 & 41 & $14.06 \pm 0.37$ & $7.89 \pm 0.21$ & $4.1 \pm 2,4$ & - & - & - \\
\hline 7 & 41 & $13.74 \pm 0.34$ & $8.08 \pm 0.20$ & $4.6 \pm 2.0$ & $25.77 \pm 1.37$ & $4.31 \pm 0.23$ & - \\
\hline 8 & 41 & $13.63 \pm 0.49$ & $8.14 \pm 0.29$ & $6.7 \pm 3.2$ & - & - & - \\
\hline 9 & 44 & $14.05 \pm 0.30$ & $7.90 \pm 0.17$ & $3.6 \pm 1.7$ & - & - & - \\
\hline 10 & 44 & - & 二 & - & $23.41 \pm 0.82$ & $4.74 \pm 0.17$ & $15.7 \pm 5.5$ \\
\hline 11 & 50 & $13.77 \pm 0.42$ & $8.05 \pm 0.25$ & $2.9 \pm 1.9$ & - & - & \pm \\
\hline 12 & 50 & $13.65 \pm 0.46$ & $8.12 \pm 0.28$ & $4.1 \pm 3.3$ & - & - & - \\
\hline 13 & 52 & $13.38 \pm 0.41$ & $8.28 \pm 0.26$ & $8.1 \pm 2.6$ & - & - & - \\
\hline 14 & 53 & $13.93 \pm 0.30$ & $7.95 \pm 0.17$ & $4.1 \pm 2.0$ & - & - & - \\
\hline 15 & 63 & - & - & - & $24.35 \pm 1.02$ & $4.54 \pm 0.19$ & $15.5 \pm 7.3$ \\
\hline 16 & 66 & $13.29 \pm 0.70$ & $8.32 \pm 0.44$ & $6.6 \pm 3.8$ & - & - & 工 \\
\hline 17 & 69 & $13.23 \pm 0.16$ & $8.35 \pm 0.10$ & - & 一 & - & - \\
\hline 18 & 74 & $13.67 \pm 0.10$ & $8.08 \pm 0.06$ & $5.4 \pm 1.0$ & - & - & - \\
\hline 19 & 75 & $13.57 \pm 0.35$ & $8.13 \pm 0.21$ & $5.4 \pm 2.6$ & - & - & - \\
\hline 20 & 79 & $13.31 \pm 0.49$ & $8.29 \pm 0.31$ & $7.6 \pm 3.5$ & - & - & - \\
\hline 21 & 86 & $14.10 \pm 0.26$ & $7.82 \pm 0.15$ & 工 & - & - & - \\
\hline 22 & 87 & 二 & - & - & $24.10 \pm 0.16$ & $4.57 \pm 0.03$ & $11.6 \pm 1.2$ \\
\hline 23 & 96 & $13.97 \pm 0.49$ & $7.88 \pm 0.28$ & - & - & - & $\overline{-}$ \\
\hline 24 & 97 & - & 工 & - & $23.34 \pm 1.29$ & $4.71 \pm 0.26$ & $13.1 \pm 7.6$ \\
\hline 25 & 98 & $13.70 \pm 0.58$ & $8.03 \pm 0.34$ & $5.3 \pm 5.3$ & $23.69 \pm 1.09$ & $4.64 \pm 0.22$ & $10.8 \pm 8.8$ \\
\hline 26 & 99 & $14.13 \pm 0.18$ & $7.78 \pm 0.10$ & $2.0 \pm 1.4$ & - & - & $=$ \\
\hline 27 & 102 & - & - & 工 & $23.39 \pm 0.72$ & $4.70 \pm 0.15$ & $14.3 \pm 4.3$ \\
\hline 28 & 103 & $13.13 \pm 0.29$ & $8.37 \pm 0.19$ & $9.1 \pm 2.3$ & $24.01 \pm 0.37$ & $4.58 \pm 0.07$ & $11.2 \pm 2.6$ \\
\hline 29 & 121 & $13.28 \pm 0.49$ & $8.25 \pm 0.31$ & $7.9 \pm 4.0$ & - & I & 工 \\
\hline 30 & 130 & $13.31 \pm 0.63$ & $8.22 \pm 0.39$ & $8.3 \pm 4.6$ & $一$ & - & - \\
\hline 31 & 135 & $13.80 \pm 0.61$ & $7.92 \pm 0.35$ & $5.1 \pm 3.6$ & - & - & 一 \\
\hline 32 & 140 & $13.72 \pm 0.45$ & $7.96 \pm 0.27$ & $4.4 \pm 3.2$ & - & - & - \\
\hline 33 & 141 & $13.53 \pm 0.51$ & $8.07 \pm 0.31$ & $7.2 \pm 4.0$ & - & - & - \\
\hline 34 & 164 & $13.37 \pm 0.03$ & $8.14 \pm 0.02$ & $7.5 \pm 0.3$ & - & - & - \\
\hline 35 & 166 & $13.46 \pm 0.08$ & $8.08 \pm 0.05$ & $6.7 \pm 0.6$ & $23.42 \pm 0.95$ & $4.64 \pm 0.19$ & $17.3 \pm 7.4$ \\
\hline 36 & 204 & $13.41 \pm 0.33$ & $8.06 \pm 0.20$ & $6.0 \pm 3.1$ & - & - & $=$ \\
\hline 37 & 205 & - & - & - & $23.78 \pm 1.45$ & $4.55 \pm 0.28$ & $17.1 \pm 12.0$ \\
\hline 38 & 223 & $13.15 \pm 0.43$ & $8.19 \pm 0.28$ & $8.9 \pm 3.6$ & $23.50 \pm 0.33$ & $4.59 \pm 0.07$ & $18.0 \pm 2.7$ \\
\hline 39 & 238 & $12.76 \pm 0.26$ & $8.4 .3 \pm 0.18$ & $12.4 \pm 2.2$ & - & - & 二 \\
\hline
\end{tabular}

per $100 \mathrm{~km}$. On the other hand the $S$ wave velocity from 40 to $220 \mathrm{~km}$ depth, increases linearly from $4.55 \mathrm{~km} / \mathrm{sec}$ to $4.64 \mathrm{~km} / \mathrm{sec}$ again with a very mild velocity gradient for $\mathrm{S}$ waves of only $0.04 \pm 0.02 \mathrm{~km} / \mathrm{sec}$ per $100 \mathrm{~km}$.

\section{Discussion}

Upper mantle velocity structure for $\mathrm{P}$ and $\mathrm{S}$ waves in the New Hebrides island arc region as determined in the present study and shown as parts (a) and (b) in Fig. 6 is compared with the upper mantle velocity structure in the Tonga-Kermadec-New Zealand region determined by KAILA and KRISHNA (1978). Upper mantle velocity structure in 

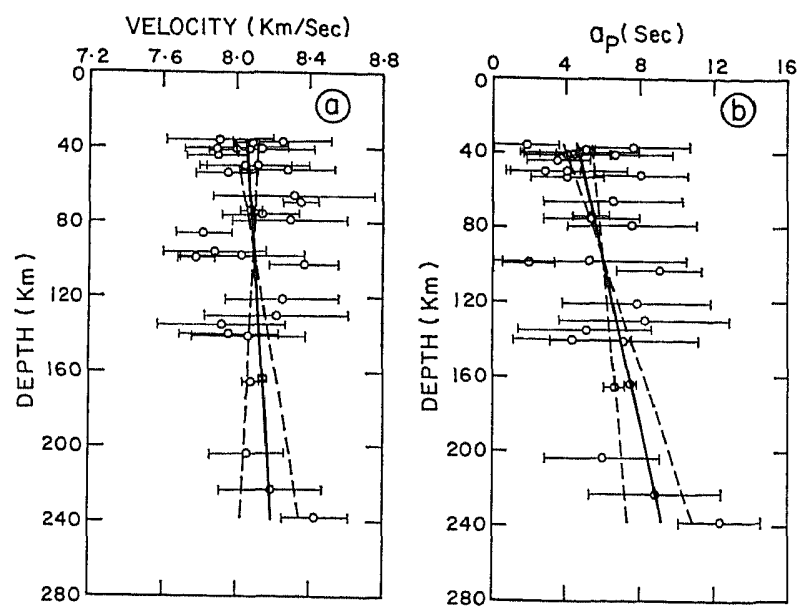

Fig. 4. (a) $\mathrm{P}$ wave velocity versus depth curve for the New Hebrides region. (b) $a_{\mathrm{P}}(=T-p \Delta)$, at the inflection point, versus depth as a calibration curve for earthquake focal depth cletermination from $\mathrm{P}$ wave data in the New Hebrides region. In both figures - are the least squares fits obtained for the plotted points shown by $O$ and --- are the $95 \%$ confidence limits of their slopes. Truncated horizontal bars represent the standard deviations in the velocity and $a_{\mathrm{P}}$ values.
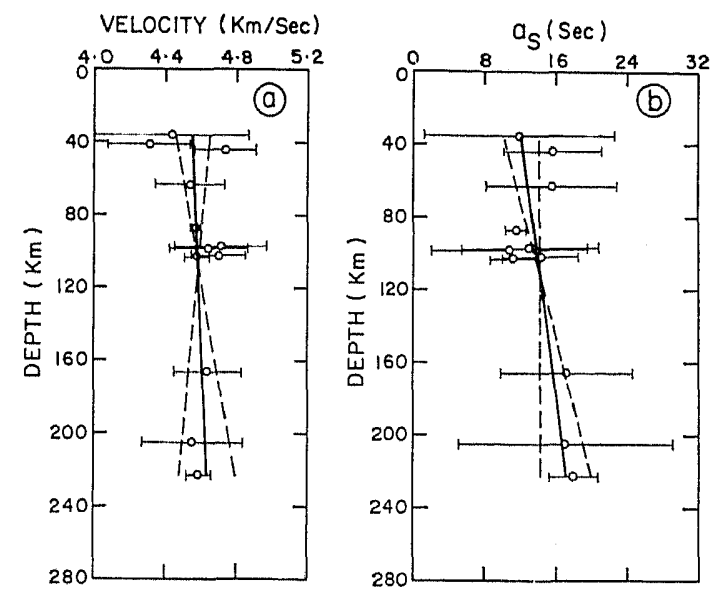

Fig. 5. (a) S wave velocity versus depth curve for the New Hebrides region. (b) $a_{\mathrm{S}}(=T-p \Delta)$, at the inflection point, versus depth as a calibration curve for earthquake focal depth determination from $\mathrm{S}$ wave data in the New Hebrides region. In both figures - are the least squares fits obtained for the plotted points shown by $O$ and -.. are the $95 \%$ confidence limits of their slopes. Truncated horizontal bars represent the standard deviations in the velocity and $a_{\mathrm{S}}$ values. 
other regions of the earth due to KaIla et al. (1971, 1974), Jefrreys (1939), Simpson et al. (1974) for $\mathrm{P}$ waves and Helmberger and Engen (1974) for $\mathrm{S}$ waves are also included in these figures for comparison. The $\mathrm{P}$ and $\mathrm{S}$ velocities at the top of the mantle in the New Hebrides seismic region as determined in the present study are 8.06 and $4.55 \mathrm{~km} / \mathrm{sec}$ respectively. Sror et al. (1971) from seismic refraction studies in the Melanesian Borderland along profile CD south of New Hebrides island and New Caledonia found $P_{n}$ velocities of $7.8 \mathrm{~km} / \mathrm{sec}$ under the Fiji plateau, and 7.7 to $8.0 \mathrm{~km} / \mathrm{sec}$ under the Norfolk ridge. Our $P$ velocity value of $8.06 \mathrm{~km} / \mathrm{sec}$ at $40 \mathrm{~km}$ depth in the New Hebrides region is quite consistent with these findings.

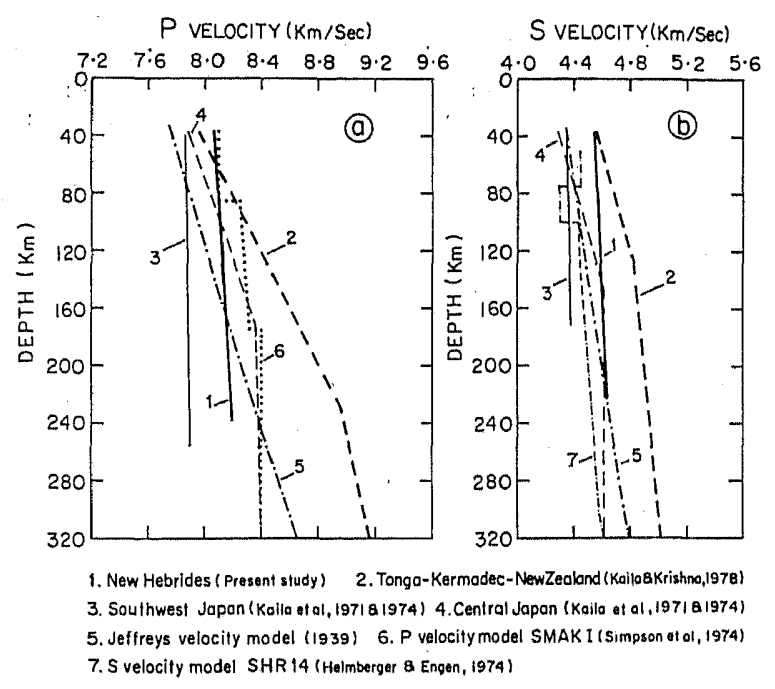

Fig. 6. (a) $\mathrm{P}$ wave and (b) $\mathrm{S}$ wave velocity functions in the New Hebrides island arc region as determined in the present study alongwith velocity models for other regions of the Earth.

The most remarkable feature that can be noticed from Fig. 6 is the gross differences in the velocity structure between the two oppositely dipping inclined seismic zones, beneath the New Hebrides island arc and the Tonga-Kermadec-New Zealand regions. It can be seen from Fig. 6 that although $P$ and $S$ velocities at the top of the mantle in the New Hebrides region are comparable with the $P$ and $S$ velocities at the top of the mantle in the Tonga-Kermadec-New. Zealand region, with increasing depth the velocity functions in the two regions show increasing divergence, the velocities in the Tonga-Kermadec-New Zealand region being substantially larger. At a depth of $240 \mathrm{~km}$, the $\mathrm{P}$ velocity in the Tonga-Kermadec-New Zealand region is about $10 \%$ higher than that in the New Hebrides region at the same depth. Similarly, at a depth of $220 \mathrm{~km}$, the S velocity in the TongaKermadec-New Zealand region is also 6 to $7 \%$ higher than that in the New Hebrides region at a similar depth. We attribute this gross difference in the velocity structure between these two seismic regions of the southwest Pacific to large lateral temperature differences in the upper mantle extending to considerable depths. The velocities of both $\mathrm{P}$ and $\mathrm{S}$ waves are strongly affected by changes in pressure, temperature and chemical and mineralogical composition which may possibly extend to great depths. Inside the 
earth both temperature and pressure increase with depth. The temperature gradient may be highly variable from place to place whereas the pressure gradient can be considered to be almost constant over various regions. The degree of compositional variation and its likely effect on the velocity structure in the two adjacent New Hebrides and the TongaKermadec-New Zealand regions can be safely assumed to be negligible, the velocities in the uppermost mantle in the two regions being almost similar. Therefore the only possible explanation that can satisfactorily account for the gross difference in the velocity structure in the two regions, in our opinion, is the temperature differences prevailing in the upper mantle. The measurements of high temperature and pressure derivatives of elastic constants for a number of compounds appropriate for geophysical considerations as reported by ANDERSON et al. (1968) indicate that a temperature contrast of the order of $1 ; 000{ }^{\circ} \mathrm{C}$ is needed to account for a $6 \%$ difference in the observed $\mathrm{P}$ velocities. Since, in the depth range from 40 to $240 \mathrm{~km}$, the average $\mathrm{P}$ velocity difference between the New Hebrides and the Tonga-Kermadec-New Zealand regions is also about $6 \%$, we therefore infer that there may be a temperature difference of about $1,000^{\circ} \mathrm{C}$ between these two regions in this depth range. At a depth of $240 \mathrm{~km}$, the temperature contrast required may be even much larger between the two regions to produce the observed $10 \% \mathrm{P}$ velocity contrast at the pressures prevailing at that depth. However, it is quite possible that this temperature excess in the New Hebrides region, may cause a partial melting which would also decrease the velocity. KANAMORI (1968) found that a $2 \%$ partial melting would cause about $1 \%$ velocity decrease using the equation $V=V_{0}(1-0.58 c)$ given by HasHiN (1962), where $V$ is the $\mathrm{P}$ velocity in a material having a liquid inclusion of concentration $c$ and $V_{0}$ is the velocity for $c=0$. Thus some component of the velocity contrast between the two regions, the New Hebrides and the Tonga-Kermadec-New Zealand may be also attributable to partial melting in the New Hebrides region and consequently the temperature contrast between the two regions may be somewhat smaller. It is therefore these high temperatures in the New Hebrides region which are primarily controlling the velocity gradients and thus keeping the $\mathrm{P}$ velocities more or less constant to a depth of $240 \mathrm{~km}$.

Let us now investigate whether these large lateral temperature variations in the upper mantle between the New Hebrides and the Tonga-Kermadec-New Zealand regions will in any way correlate with the observed heat flow in the two regions. In Fig. 1, we have also shown the heat flow observations in the southwest Pacific region compiled by JEssop et al. (1976). We have, however, classified the heat flow values only into 3 ranges as shown in Fig. 1, instead of 5 ranges given by Jessop et al. (1976). It can be seen from Fig. 1 that the average observed heat flow value in the eastern north island of New Zealand and in the Tonga-Kermadec deep earthquake zone is much smaller than that in the New Hebrides seismic zone. Thus the distribution of the observed heat flow in the two regions is also quite consistent with our idea that the temperatures in the New Hebrides region are much larger than those in the Tonga-Kermadec-New Zealand region. These high temperatures in the New Hebrides region may also imply that the mantle material in this region down to at least $240 \mathrm{~km}$ is probably in a partially molten state and the chain of active volcanoes also nicely correlates with this idea (see Fig. 1).

In Fig. 6 we have also shown the $\mathrm{P}$ and $\mathrm{S}$ velocity functions for the southwest and central Japan regions determined by KAILA et al. (1971 and 1974). It is very interesting to note that the difference in the velocity structures between the southwest Japan and the central Japan regions is quite similar to that found by us between the New Hebrides and the Tonga-Kermadec-New Zealand regions. The velocity in the southwest Japan region 
almost remains constant to the depth studied, about $255 \mathrm{~km}$ for $\mathrm{P}$ waves and about $170 \mathrm{~km}$ for $\mathrm{S}$ waves. On the other hand, although the velocities at the top of the mantle in the southwest and central Japan regions are comparable, the velocities of both $\mathrm{P}$ and $\mathrm{S}$ waves in the central Japan region increase with high velocity gradients in this depth range. Thus the velocity functions in the southwest and central Japan regions also show increased divergence with increasing depths. In our opinion, these velocity anomalies are also caused by only large lateral temperature contrasts between the southwest and the central Japan regions. KaIlA et al. $(1971,1974)$ interpreted the constant $\mathrm{P}$ and $\mathrm{S}$ velocities in the upper mantle beneath the southwest Japan region as due to relatively high volcanic activity and probable existence of large magma chamber extending to about $250 \mathrm{~km}$ depth beneath southwest Japan.

If we compare the velocity structure in the New Hebrides and the southwest Japan regions we can find that although the velocities remain constant in both the regions, the velocities in the southwest Japan region are about 3\% lower for $\mathrm{P}$ waves and about 4\% lower for $\mathrm{S}$ waves than those in the New Hebrides region. This may imply that the temperature at the top of the mantle beneath the New Hebrides may be smaller than that in the southwest Japan region. However, the temperature gradients in the two regions may be comparable because the velocities remain almost constant upto about $240 \mathrm{~km}$. Of course, we cannot rule out the possibility that some component of the observed velocity anomaly between these two regions, the New Hebrides (in the southwest Pacific) and the southwest Japan may be also due to some compositional change, the two regions being so wide apart. However, the compositional change, even if it exists to some extent in the uppermost mantle immediately below Moho, may not be able to account for the observed velocity anomaly at large depth, which can be only explained by temperature differences between the two regions.

JefFreys (1939) velocity curves for both $P$ and $S$ waves are also shown in Fig. 6 . The $P$ velocities in the New Hebrides region to a depth of about $160 \mathrm{~km}$ are found to be comparatively higher and they are somewhat lower between 160 to $240 \mathrm{~km}$ than those given by JEFFREYs (1939). On the other hand, the $\mathrm{S}$ velocities are also relatively higher in the New Hebrides region than those given by JEFFREYs (1939) throughout the depth range of $220 \mathrm{~km}$ studied. The $\mathrm{P}$ velocity model SMAK I for northeastern Australia given by Simpson et al. (1974) also reveals very small velocity gradient comparable with the $\mathrm{P}$ velocity gradient for the New Hebrides region determined in the present study. It may be mentioned here, that the source region involved in deriving the SMAK I model is New Guinea, New Britain and Solomon islands region which is also an active volcanic region and a region of high heat flow (see Fig. I) as the New Hebrides region. These observations again substantiate our idea that the temperatures may be considerably higher in these regions therefore the velocity gradients in both the regions are very small. In fact the mantle material in the entire region, beneath the New Hebrides, Solomon islands, New Britain and the New Guinea regions may be in a partially molten state as evidenced by intense volcanism and high observed heat flow in these regions. Therefore, the velocity gradients in these regions are extremely small. However, since some correction to remove the source effect to some extent, is applied by Simpson et al. (1974) the SMAK I model is therefore revealing somewhat higher velocities than our $\mathrm{P}$ velocity curve for the New Hebrides region in the depth range from 90 to $240 \mathrm{~km}$. Brooks (1962) determined P velocities to a depth of $500 \mathrm{~km}$ in the New Guinea-Solomon Islands region from the analysis of travel times using Gutenberg's (1953) graphical method, and presented evidence 
for the existence of a low velocity zone in the region. According to him, the minimum velocity reached may be as low as $7.6 \mathrm{~km} / \mathrm{sec}$ at a depth of about $150 \mathrm{~km}$ and the decrease in velocity in that region is much more pronounced than reported by other workers and that shadow zones for the arrival of direct $\mathrm{P}$ waves exist in the area. The $\mathrm{S}$ velocity model SHR 14, given by Helmberger and ENGen (1974), applicable for the western United States has a low velocity layer between depths of 80 to $100 \mathrm{~km}$ and it reveals somewhat lower velocities than our $\mathrm{S}$ velocity curve for the New Hebrides region.

Dubors et al. (1973) from the study of $\mathrm{P}$ and $\mathrm{S}$ times from shallow earthquakes between the New Hebrides and Fiji found that in the centre of the Fiji plateau the velocities for $\mathbf{P}$ and $\mathrm{S}$ waves in the uppermost mantle are 7.70 and $4.30 \mathrm{~km} / \mathrm{sec}$ respectively. They have also found that along the seismically active margins of the plateau $\mathrm{P}$ velocities are only $7.30-7.40 \mathrm{~km} / \mathrm{sec}$. According to Dubors et al. (1973) the zone of low velocity beneath the Fiji plateau has its boundaries which seem to coincide with a high seismic wave attenuation zone that exists in the uppermost mantle between the Fiji and the New Hebrides islands. BARAzANG $e$ t al. (1974) studied $\mathrm{P}$ and $\mathrm{S}$ seismic waves produced by hundreds of earthquakes located along the New Hebrides, Fiji plateau, Solomon, New Britain and New Guinea seismic zones and recorded at stations in Fiji, New Hebrides and New Caledonia. They found significant variations in the amplitudes and frequencies of the waves. Their data defined zones of anomalously high seismic wave attenuation in the uppermost mantle beneath the Fiji plateau and the Woodlark basin south of the Solomon islands. BARAZANGI and IsACKS (1971) also mapped in detail a zone of anomalously high seismic wave attenuation under the Lau basin. All these areas are also the sites of variable but generally high heat flow (ScLATter et al., 1972; MACDonAld et al., 1973) and low seismic wave velocities (Dubors et al., 1973; Aggarwal et al., 1972; Sror et al., 1971, Furumoto et al., 1970). All these results suggest that hot and probably partially melted upper mantle material exists beneath these areas. It is also evident from our Fig. 1 that the observed heat flow in the Fiji plateau and other anomalous regions is considerably higher. BARAzANGI et al. (1974) also found that the high attenuation zone extends to depths of at least $300 \mathrm{~km}$ beneath the Fiji plateau. This implies that the temperatures of the mantle material beneath the Fiji plateau to a depth of about $300 \mathrm{~km}$ are relatively much higher than those in the surrounding mantle. It is quite possible that, the high temperatures probably prevailing to great depths of about $300 \mathrm{~km}$ beneath the Fiji plateau are even affecting the northeasternly dipping New Hebrides seismic zone to a considerable extent and that the temperatures in the dipping seismic zone are also very high. That is why the velocity gradients of $\mathrm{P}$ and $\mathrm{S}$ waves in the New Hebrides seismic zone as determined by us are extremely small thus the $\mathrm{P}$ and $\mathrm{S}$ velocities are also much lower in the New Hebrides region as compared to those in the Tonga-Kermadec-New Zealand region at comparable depths.

BARAZANGI et al. (1973) studied the seismic wave propagation in the mantle beneath the New Hebrides island arc and presented evidence for the detachment of lithospheric slabs in the upper mantle beneath the New Hebrides arc. They interpreted the remarkable gap in the seismic activity between deep and intermediate depth earthquakes at the northern part of the arc as due to a gap in the lithospheric slab descending beneath the arc, and the deep earthquakes as due to a detached piece of lithosphere. They found that predominently low frequency (about $0.5 \mathrm{~Hz}$ ) S waves are recorded at PVC and LNR stations in the New Hebrides from the deep earthquakes north of $15^{\circ} \mathrm{S}$. New Hebrides deep earthquakes located at the western part of the deep zone produced attenuated, low 
frequency $\mathrm{S}$ waves at PVC. The ray paths pass just beneath the dipping seismic zone. BARAzANGi et al. (1973) found that frequencies greater than $1 \mathrm{~Hz}$ are absent and the amplitude of the $\mathrm{S}$ phase is generally less than that of $\mathrm{P}$ phase. As OLIVER and IsAcrs (1967) and BARAZANGI and IsACKs (1971) showed, this can be explained by a transmission through an attenuating low $Q$ zone. BARAzANGI et al. (1973) also found that in contrast, $\mathrm{S}$ waves recorded at NIU station on the Tonga island arc from Tongan deep earthquakes have predominent frequencies of 3-4 Hz and the amplitude of $\mathrm{S}$ are generally larger than those of $\mathrm{P}$. They interpreted the observation of low frequency $\mathrm{S}$ waves at PVC and LNR to be mainly the result of attenuation along the path. According to them the attenuation is chiefly below $300 \mathrm{~km}$. BARAZANGI et al. (1973), on the basis of all these observations, suggested that there is absence of lithospheric slab material between depths of about 300 and $600 \mathrm{~km}$, and the deep earthquakes of New Hebrides therefore represent a detached slab in the upper mantle. In our opinion, the very high temperatures reached at about $300 \mathrm{~km}$ depth in the surrounding mantle have probably affected the New Hebrides seismic zone to such an extent that the material in the seismic zone also has lost its strength substantially and no stresses can be accumulated in it. FARBEROV and GoreLchrK (1971) studied the focal distribution of subcrustal earthquakes and the dynamic features of seismic wave propagation under some volcanic areas of Kamchatka. They found that under active volcanoes there are aseismic areas of anomalous attenuation of seismic waves. As one of many possibilities, they suggested the presence of low viscosity zones under volcanoes in which there are no concentration of sufficient stresses to generate earthquakes and that these zones extend down to the focal layer. Since the volcanic activity in the New Hebrides region is also quite extensive the large temperatures there might have also reduced the viscosity of the mantle material at depths considerably. Thus beyond the depth of about $300 \mathrm{~km}$ there seems to be a gap in the seismic activity in this region. Again at depths greater than $600 \mathrm{~km}$, due to increased pressure, built up by the usual pressure gradient, the material in the seismic zone might have recovered the necessary strength again to accumulate the stresses and therefore there are earthquakes occurring at these depths. Therefore, if we view the properties of the seismic zone in the light of this argument there is no necessity to imagine a gap in the lithospheric slab between depths of 300 $600 \mathrm{~km}$ and a detached piece of lithosphere at about $600 \mathrm{~km}$ depth. The lithospheric slab in the New Hebrides may as well be continuing down to the usual depth of its penetration, i.e., probably the $650 \mathrm{~km}$ velocity discontinuity in the mantle. It may be only because of the anomalously high temperatures attained at depths beyond about $300 \mathrm{~km}$, that the seismic activity is not continuing between $300-600 \mathrm{~km}$ depths. This does not necessarily mean that there is a gap in the lithospheric slab itself. The gap according to us, is only the change in the physical properties of the lithospheric slab but not its existence as such.

BARAZANGi et al. (1973) found that one of the three deep earthquakes occurred south of $15^{\circ} \mathrm{S}$ at about $18^{\circ} \mathrm{S}$ and $173^{\circ} \mathrm{E}$ produced large amplitude, high frequency $\mathrm{S}$ waves at PVC station in the New Hebrides. According to them this observation is quite clear and may imply the continuity of descending slab in the southern part of the New Hebrides arc. ISACKS and MOLNAR (1971) suggested that the gaps in seismic activity as a function of depth can be explained by two models. In the first the stress inside a continuous slab varies from downdip extension at intermediate depths to downdip compression at greater depths, and thus is near zero between these depths. In the second a piece of descending lithosphere breaks off, sinks into the upper mantle and leaves a gap between the piece and the plate 
to which it was attached. Sykes (1966) studied the seismic activity versus depth for several island arcs. He found that in all island arcs studied the activity decreases in the upper 100 to $200 \mathrm{~km}$ approximately exponentially as a function of depth with a decay constant of about $100 \mathrm{~km}$. IsACKs et al. (1968) found that there is an approximate correlation of the decrease in seismic activity versus depth with a similar general decrease in seismic velocities, $Q$ and viscosity in the upper $150 \mathrm{~km}$. They stated that these effects may be related to a decrease in the difference between the temperature and local melting temperature.

IsACKs et al. (1968) have plotted in their Fig. 12 the annual number of earthquakes per $25 \mathrm{~km}$ depth intervals as function of depth for several island arcs, the data being taken by them from Sykes (1966) and from Katsumata (1967) for the Japan region. If we scrutinize these curves carefully, we can find that there is either a broad minimum between depths of about 200 to $400 \mathrm{~km}$ or there are some gaps in certain depth ranges. We can notice broad minima for the Japan and the Tonga-Fiji-Kermadec regions in almost the same depth range where the $\mathrm{P}$ velocity functions reveal reduced velocity gradients in these regions (KAILA et al., 1971; KAILA and KRIsHNA, 1978). In our opinion, this is a nice correlation between the zones of less seismic activity and zones of reduced velocity gradients. Both these phenomenon can be easily explained by means of very high temperatures and/or temperature gradients in these depth ranges. Therefore, it is also quite possible that in a region like the New Hebrides which is surrounded by anomalously hot regions of the mantle there may be actual gap in the seismic activity in certain depth range like 300-600 km. In our opinion, this gap in the seismic activity however, does not necessarily mean a gap in the lithospheric slab. The slab may be actually continuing right to its maximum depth of penetration which may be the $650 \mathrm{~km}$ seismic discontinuity with variable physical properties throughout its length as explained above.

\section{Conclusions}

From the present study of the travel times of $\mathrm{P}$ and $\mathrm{S}$ waves in the New Hebrides island arc region we can make the following conclusions regarding the upper mantle structure in that region.

1) The $P$ and $S$ velocities are almost constant in the upper mantle to a depth of about $240 \mathrm{~km}$. These velocities, although are comparable at the top of the mantle, they are however, much lower, by as much as $10 \%$ for $\mathrm{P}$ waves and $6-7 \%$ for $\mathrm{S}$ waves at a depth of about $240 \mathrm{~km}$ as compared to those at similar depths in the Tonga-Kermadec-New Zealand region. A temperature contrast of about $1,000^{\circ} \mathrm{C}$ between these two regions is needed to account for these velocity anomalies on the average.

2) The lower velocities observed in the New Hebrides seismic zone, are primarily due to anomalously high temperatures prevailing even at great depths in the upper mantle surrounding the New Hebrides region. In fact, the mantle material in the entire region beneath the New Hebrides, Solomon islands, New Britain and New Guinea regions may be in a partially molten state as revealed by very mild velocity gradients, high heat flow and intense volcanism in these regions.

3) The remarkable gap in the seismic activity observed in the New Hebrides region between depths of 300-600 km need not necessarily mean a gap in the lithospheric slab descending beneath the New Hebrides island arc. It is only due to the anomalously high temperature, prevailing in this region that the descending slab also has probably lost its 
strength considerably and therefore cannot take sufficient stresses to accumulate and subsequently release through the earthquakes. At depths of about $600 \mathrm{~km}$ again the material in the slab has probably recovered its strength and therefore there are deep earthquakes at these depths. Therefore, we conclude that the lithospheric slab descending beneath the New Hebrides region is not broken between $300-600 \mathrm{~km}$ depth and may be continuing with varying physical and thermal properties right to the maximum depth of its penetration which may extend upto the $650-\mathrm{km}$ seismic discontinuity.

We are grateful to Dr. Hari Narain, Director, National Geophysical Research Institute for providing all the facilities to carry out this research work and for his permission to publish this paper. Our thanks are also due to Mr. G. Khandekar for his help in the data collection and some computations. Preparation of the tracings of various drawings by Mr. P.J. Vijayanandam is duly acknowledged.

\section{REFERENCES}

Aggarwal, Y.P., M. Barazangi, and B. Isacks, P and S travel times in the Tonga-Fiji region: A zone of low velocity in the uppermost mantle behind the Tonga island arc, J. Geophys. Res., 77, 6427-6434, 1972.

Anderson, O.L., E. Schreiber, R.C. Liebermann, and N. Soga, Some elastic constrant data on minerals relevant to geophysics, Rev. Geophys., 6, 491-524, 1968.

BARAZANGI, M. and B. IsACKs, Lateral variations of seismic wave attenuation in the upper mantle above the inclined earthquake zone of the Tonga island arc: Deep anomaly in the upper mantle, J. Geophys. Res., 76, 8493-8516, 1971.

Barazangi, M., B.L. Isacks, J. Olrver, J. Dubois, and G. Pascal, Descent of lithosphere beneath New Hebrides, Tonga-Fiji and New Zealand: Evidence for detached slabs, Nature, 242, 98-101, 1973.

Barazangi, M., B. Isacks, J. Dubors, and G. Pascal, Seismic wave attenuation in the upper mantle beneath the southwest Pacific, Tectonophysics, 24, 1-12, 1974.

Brooks, J.A., Seismic wave velocities in the New Guinea-Solomon Islands region, in The Crust of the Pacific Basin, Geophys. Monogr., 6, 2-10, 1962.

Dubors, J., G. Pascal, M. Barazangr, B.L. Isacks, and J. Oliver, Travel times of seismic waves between the New Hebrides and Fiji islands: A zone of low velocity beneath the Fiji plateau, J. Geophys. Res., 78, 3431-3436, 1973.

Farberov, A.I. and V.I. Gorelchik, Anomalous seismic effect under volcanoes and some features of deep seated structure of volcanic areas, Bull. Volcanol., 35, 212-224, 1971.

Furumoto, A., D. Hussong, J. Campbell, G. Sutton, A. Malafiofr, J. Rose, and G. Woollard, Crustal and upper mantle structure of the Solomon islands as revealed by seismic refraction survey of NovemberDecember, 1966, Pac. Sci., 24, 315, 1970.

Gutenberc, B., Wave velocities at depths between 50 and 600 kilometers, Bull. Seismol. Soc. Am., 43, 223-232, 1953.

Hasfin, Z., The elastic moduli of heterogeneous materials, J. Appl. Mech., 29, 143-150, 1962.

Helmberger, D.V. and G.R. Engen, Upper mantle shear structure, J. Geophys. Res, , 79, 4017-4028, 1974.

Isacks, B. and P. MolnaR, Distribution of stresses in the descending lithosphere from a global survey of focal mechanism solutions of mantle earthquakes, Rev. Geophys. Space Phys., 9, 103-174, 1971.

Isacks, B., J. Oliver, and L.R. Sykes, Seismology and the new global tectonics, J. Geophys. Res., 73, 5855$5899,1968$.

Jefrreys, H., The times of $\mathrm{P}, \mathrm{S}$, and SKS and the velocities of $\mathrm{P}$ and $\mathrm{S}$, monthly notices, Roy. Astron. Soc. Geophys., 4 (Suppl.), 498-533, 1939.

Jessop, A.M., M.A. Hobart, and J.G. Sclater, Terrestrial heat flow data, Map produced by P.J. Grim, National Geophysical and Solar-Terrestrial Data Center, (U.S.A.), 1976.

KAILA, K.L., A new analytical method for finding the upper mantle velocity structure from P and S wave travel times of deep earthquakes, Bull. Seismol. Soc. Am., 59, 755-769, 1969.

KAILA, K.L. and V.G. KrusernA, Upper mantle velocity structure in the Tonga-Kermadec island arc region, Paper presented at the International Geodynamics Conference, March 13-17, Tokyo, Japan, 1978.

KAILA, K.L., V.G. KRISHNA, and Hari NARAIN, Upper mantle $P$ wave velocity structure in the Japan region from travel time studies of deep earthquakes using a new analytical method, Bull. Seismol. Soc. Am., 61, 1549-1570, 1971.

KAILA, K.L., V.G. KRISHNA, and Hari NaraIn, Upper mantle shear wave velocity structure in the Japan region, Bull. Seismol. Soc. Am., 64, 355-374, 1974. 
KANAMORI, H., Travel times to Japanese stations from Longshot and their geophysical implications, Bull. Earthq. Res. Inst. Tokyo Univ., 46, 841-859, 1968.

Katsumata, M., Seismic activities in and near Japan 3: Seismic activities versus depth, J. Seismol. Soc. Jpn., 20, 75, 1967 (in Japanese).

MacDonald, G.A., Volcanoes, Prentice-Hall, Englewood Cliffs, New Jersey, 1972.

MacDonald, K., B. LuYendyk, and W. Bryan, Heat flow and plate boundaries in Melanesia, J. Geophys. Res., 78, 2537-2546, 1973.

Oliver, J. and B. IsAcks, Deep earthquake zones, anomalous structures in the upper mantle, and the lithosphere, J. Geophys. Res., 72, 4259-4275, 1967.

Pascal, G., J. Dubois, M. Barazangr, B.L. Isacks, and J. Oliver, Seismic velocity anomalies beneath the New Hebrides island arc: Evidence for a detached slab in the upper mantle, J. Geophys. Res., 78, 6998$7004,1973$.

Sclater, J., U. Ritter, and F. Dixon, Heat flow in the southwestern Pacific, J. Geophys. Res., 77, 5697-5704, 1972.

Shor, G., H. Krrk, and H. Menard, Crustal structure of the Melanesian area, J. Geophys. Res., 76, 2562$2586,1971$.

Simpson, D.W., R.F. Mereu, and D.W. King, An array study of P-wave velocities in the upper mantle transition zone beneath northeastern Australia, Bull. Seismol. Soc. Am., 64, 1757-1788, 1974.

Sykes, L.R., The seismicity and deep structure of island arcs, J. Geophys. Res., 71, 2981-3006, 1966. 